\section{IAC 1850: High yielding carioca common bean cultivar}

\author{
Sérgio Augusto Morais Carbonell ${ }^{1 *}$, Alisson Fernando Chiorato ${ }^{1}$, \\ Luiza Maria Capanema Bezerra ${ }^{1}$, João Guilherme Ribeiro \\ Gonçalves ${ }^{1}$, Daiana Alves da Silva ${ }^{1}$, Jose Antonio de Fatima \\ Esteves ${ }^{1}$, Luciana Lasry Benchimol-Reis ${ }^{1}$, Cassia Regina Limonta \\ Carvalho ${ }^{1}$, Vera Lúcia Nishijima Paes de Barros ${ }^{2}$, Rogério Soares \\ de Freitas ${ }^{3}$, Marcelo Ticelli ${ }^{4}$ and Paulo Boller Gallo ${ }^{5}$
}

\begin{abstract}
IAC 1850 is a common bean cultivar with a carioca (beige-colored with brown stripes) seed coat, average cycle of 88 days, semi-upright plant architecture, tolerance to seed coat darkening, 1000 seed weight of 280 grams, resistance to the main diseases in common bean, and a high average yield $(2,857$ $\mathrm{kg} \mathrm{ha}^{-1}$ ) obtained in 36 experiments conducted in different regions in Brazil.
\end{abstract}

Keywords: Phaseolus vulgaris L., plant breeding, resistance to darkening, disease resistance.

\section{INTRODUCTION}

Common bean (dry edible bean or simply "beans") is one of the most important legume crops in Brazil and throughout the world, it is considered a staple and lowcost protein source, consumed in several under-developed countries, an excellent source of fiber, iron and amino acids (CIAT 2016). Furthermore, beans strongly reinforce food and nutrition security among poor consumers, while according to Li et al. (2017) its consumption also reducing the risk of cardio-vascular disease and diabetes.

Common bean is grown in diverse regions of the world, but it is most highly concentrated in areas of tropical and subtropical climate (Singh et al. 1992). Although it is grown throughout Brazil and is considered a staple food for the population, yield is considered to be low. Mean yield of carioca bean in the three annual crop seasons, according to CONAB (2018), was 1,379 $\mathrm{kg} \mathrm{ha}^{-1}$, whereas the crop has a yield potential of up to $4,500 \mathrm{~kg} \mathrm{ha}^{-1}$ (Wutke et al. 2014). One of the common bean cultivars classified as "colored" by the Companhia Nacional de Abastecimento - Conab (National Food Supply Agency) is carioca (beige/ cream-colored with brown stripes), which corresponds to approximately $65 \%$ of common bean production in Brazil in 2006 according to Silva and Wander (2013).

Factors responsible for low yield of common bean include the technologies used in growing the crop, such as inadequate use of machines and implements and the lack of use of recommended fertilizers, soil amendments, and irrigation; biotic factors such as pests, diseases, and weeds; and abiotic factors such as thermal variations, water deficit, and edaphic factors concerning the chemical composition, structure, compaction, low fertility, and acidity of the soil (Fageria et al. 2015).
Crop Breeding and Applied Biotechnology 19:3, 378-381, 2019 Brazilian Society of Plant Breeding. Printed in Brazil http://dx.doi.org/10.1590/1984$70332019 v 19 n 3 c 53$

\footnotetext{
*Corresponding author: E-mail: scarbonell@iac.sp.gov.br (D) ORCID: 0000-0003-2964-972X
}

Received: 16 April 2019 Accepted: 29 May 2019

${ }^{1}$ Instituto Agronômico de Campinas, 13.020902, Campinas, SP, Brazil

${ }^{2}$ Agência Paulista de Tecnologia dos Negócios, Pólo Regional de Desenvolvimento Tecnológico do Agronegócio, Sudoeste Paulista, 18.300-970, Capão Bonito, SP, Brazil

${ }^{3}$ Instituto Agronômico, Centro APTA de Seringueira e Sistemas Agroflorestais, Zona rural, 15.500-000, Votuporanga, SP, Brazil ${ }^{4}$ Agência Paulista de Tecnologia dos Negócios Sudoeste Paulista, Pólo Regional de Desenvolvimento Tecnológico do Agronegócio, km 38, 18.300-970, Tatuí, SP, Brazil ${ }^{5}$ Agência Paulista de Tecnologia dos Negócios Nordeste Paulista, Pólo Regional de Desenvolvimento Tecnológico do Agronegócio, 13.730-980, Mococa, SP, Brazil 
Due to concentration of production in carioca bean, Brazilian farmers have had to bear price declines in periods in which product stocks increase and supply is excessive. For carioca bean production, sale of excess stocks on the international market is not an alternative because there is low demand for this type of common bean, unlike pinto beans (cream-colored with brown specks). Therefore, common bean breeding programs become extremely important to be able to exploit the variability of the species to reduce costs, create business opportunities, and stimulate consumption.

In the Common Bean Breeding Program at the Instituto Agronômico - IAC (PMGF-IAC), genetic studies guide definition of the methods used for crop breeding, which must be increasingly efficient to develop adapted cultivars that maintain yield under growing conditions in unfavorable locations. The breeder needs to consider various factors besides yield; genotypes need to meet criteria of agronomic interests and market demands, such as resistance to the main diseases of common bean, resistance to abiotic factors, shorter cooking time, resistance to seed coat darkening, and a high percentage of beans that remain whole after cooking (Carbonell et al. 2010).

The goal of breeding programs is to develop common bean cultivars that increase production, trade, and consumption, together with agronomic management of the crop considering low cost, environmental conservation, nutritional quality, and product technology. Thus, the cultivar IAC 1850 was developed by the PMGF-IAC to meet these requirements. It was registered in 2018 under number 38613 in the National Cultivar Registry of the Brazilian Ministry of Agriculture (MAPA/RNC).

\section{GENETIC ORIGIN AND DEVELOPMENT}

The cultivar IAC 1850 originated in 2012 in a cross between the lines Seleção 940 x Seleção 847 as part of the PMGFIAC for carioca common bean. The parents involved in this cross were progenies of selections involving several multiple crosses for improving characteristics of resistance to anthracnose and to fusarium wilt, upright plant architecture, stability in production in diverse environments, and high yield. In 2013, $15 F_{1}$ seeds were sown in a greenhouse to obtain 684 seeds of the $F_{2}$ generation, which were conduct by pedigree breeding method. The $F_{2}$ seedlings were inoculated with a mixture of races 65, 81 and 321 of the anthracnose (Coletotrichum lindemuthianum) pathogen under controlled laboratory conditions, and $32 \mathrm{~F}_{2: 3}$ resistant seedlings were obtained in 2014. Also in 2014, the $32 \mathrm{~F}_{2: 3}$ progenies were evaluated in the field for reaction to fusarium wilt (Fusarium oxysporum) and 125 individual $F_{2: 4}$ plants were selected. The 125 progenies of the $\mathrm{F}_{2: 4}$ generation were sown in five-meter rows in the research and development unit in the municipality of Capão Bonito-SP (UPD - IAC Capão Bonito), for evaluation of diverse agronomic characteristics. Four $F_{2: 5}$ plants of the progeny number 90 were selected and codified under the numbers Gen90-1A, Gen90-2A, Gen90-3A and Gen90-4A. The "Gen" abbreviation refers to the PMGF-IAC and the letter "A" corresponds to anthracnose resistance, as the progenies were subjected to anthracnose in the $F_{2}$ generation.

In the 2015 dry crop season, the four $F_{2: 5}$ lines were sown in the research and development unit UPD-IAC Mococa in the municipality of Mococa-SP, using a randomized block statistical design with three replications. In the winter crop season of the same year, the four lines were sown with other lines of the PMGF-IAC at the Centro Avançado de Seringueira e Sistemas Agroflorestais - IAC, in the municipality of Votuporanga, SP, for evaluation of reaction to fusarium wilt, and the line Gen90-4A was selected. This line came to be designated as Gen90-4A-160. The number 160 corresponds to the field plot position of the Gen90-4A line. The Gen90-4A-160 line was sown in the 2015 rainy crop season on the Santa Elisa Farm of the Instituto Agronômico - IAC in the municipality of Campinas, SP. In this evaluation, the line had excellent agronomic performance and was recommended together with other lines to compose the Value of Cultivation and Use - VCU trials for the 2016/2017 biennial period.

\section{YIELD CAPACITY}

The VCU experiments were conducted in 36 environments over the years 2016 and 2017 in three sowing seasons and in municipalities of the states of São Paulo and Goiás (Table 1). The cultivars used as controls for the carioca group were IAC Milênio and BRS Perola. The line Gen90-4A-160 (IAC 1850) had excellent agronomic performance for yield (Table 1). In twelve environments per crop season in two years of evaluation, the line Gen90-4A-160 (IAC 1850) showed a mean yield of 2,975 $\mathrm{kg} \mathrm{ha}^{-1}, 2,607 \mathrm{~kg} \mathrm{ha}^{-1}$, and 2,989 $\mathrm{kg} \mathrm{ha}^{-1}$ in the rainy, dry, and winter crop seasons, respectively, compared to the mean yield values of the two controls per crop season of 2,566 kg ha-1, 2,252 $\mathrm{kg} \mathrm{ha}^{-1}$, and 2,596 kg ha-1, 
respectively. In combined analysis of the three crop seasons, the mean yield of the line Gen90-4A-160 (IAC 1850) was $2,857 \mathrm{~kg} \mathrm{ha}^{-1}$ and the mean of the control cultivars was $2,463 \mathrm{~kg} \mathrm{ha}^{-1}$.

\section{OTHER CHARACTERISTICS}

The plant of the cultivar IAC 1850 has semi-upright plant architecture and type II indeterminate growth habit. Its mean cycle is 90 days from emergence to physiological maturity, in accordance with crop growing conditions, considered to be intermediate cycle. The cultivar IAC 1850 has carioca beans with a beige-colored seed coat with brown stripes.

Table 1. Bean seed yield $\left(\mathrm{kg} \mathrm{ha}^{-1}\right)$ in $2016 / 2017 \mathrm{VCU}$ experiments grown in 36 environments in three crop seasons

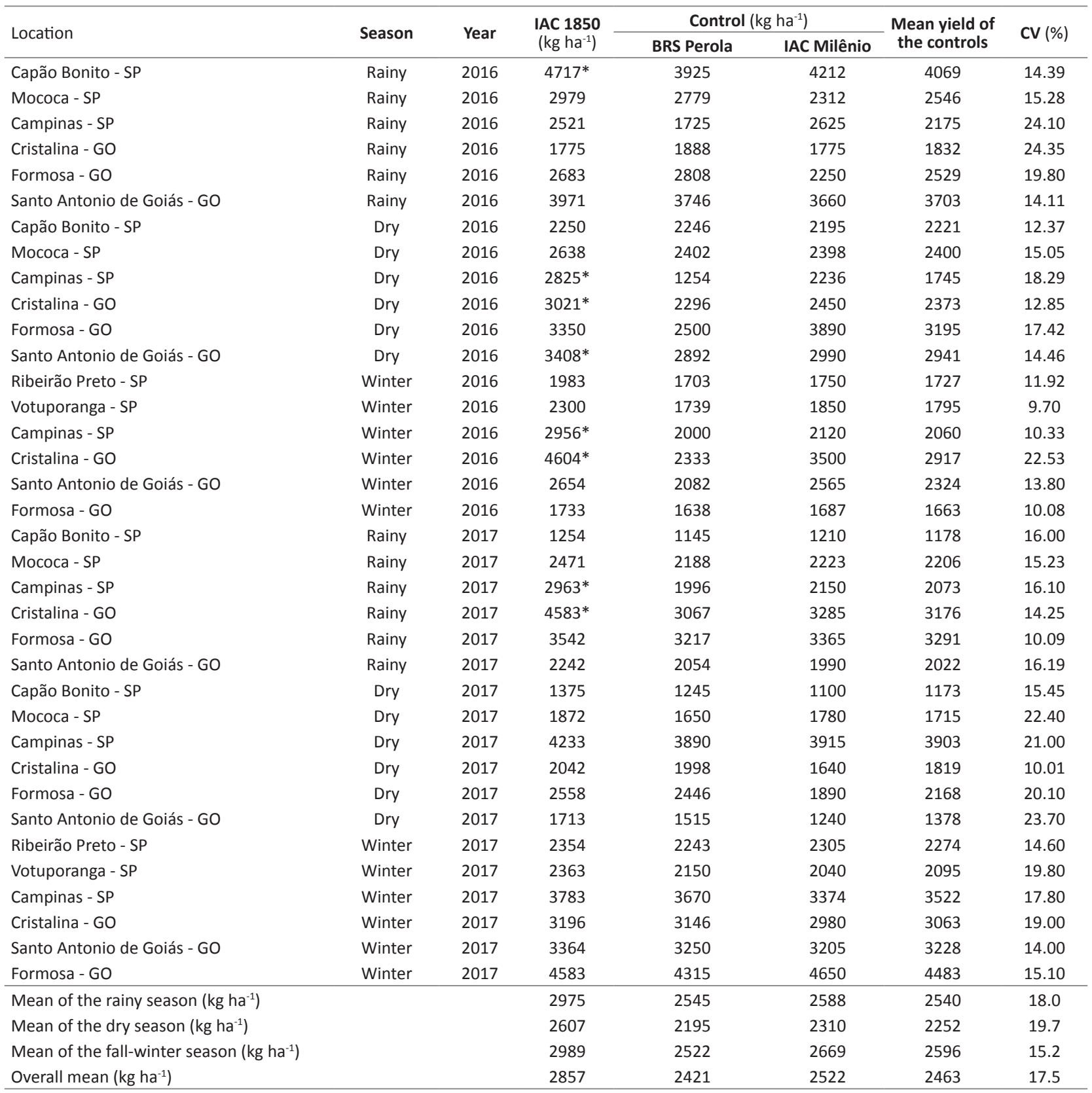

* Dunnett test $(p>0.05)$ 
IAC 1850: High yielding carioca common bean cultivar

Table 2. Technological and nutritional quality: mean values of cooking time by the Mattson cooker and protein percentage in common bean seeds grown in the 2016/2017 biennial period.

\begin{tabular}{|c|c|c|c|c|c|c|}
\hline \multirow[b]{2}{*}{ Season } & \multicolumn{2}{|c|}{ IAC 1850} & \multicolumn{2}{|c|}{ IAC Milênio } & \multicolumn{2}{|c|}{ BRS Pérola } \\
\hline & $\begin{array}{l}\text { Cooking Time } \\
(\min )\end{array}$ & $\begin{array}{c}\text { Protein Content } \\
(\%)\end{array}$ & $\begin{array}{l}\text { Cooking Time } \\
\text { (min) }\end{array}$ & $\begin{array}{c}\text { Protein Content } \\
(\%)\end{array}$ & $\begin{array}{l}\text { Cooking Time } \\
(\mathrm{min})\end{array}$ & $\begin{array}{c}\text { Protein Content } \\
(\%)\end{array}$ \\
\hline Winter 2016 & 33.31 & 19 & 33.30 & 20 & 35.21 & 19 \\
\hline Rainy 2016 & 29.30 & 21 & 30.35 & 19 & 35.25 & 20 \\
\hline Rainy 2017 & 30.31 & 18 & 32.50 & 21 & 30.03 & 21 \\
\hline Mean & 30.90 & 20 & 31.04 & 20 & 32.19 & 20 \\
\hline
\end{tabular}

The mean 1000 seed weight is 280 grams, and it is resistant to early seed coat darkening.

Under natural growing conditions, the cultivar IAC 1850 is moderately resistant to anthracnose (Colletotrichum lindemuthianum), to angular leaf spot (Phaeoisariopsis griseola), to fusarium wilt (Fusarium oxysporum), to common bacterial blight (Xanthomonas axonopodis pv. phaseoli), and to bacterial wilt (Curtobacterium flaccumfaciens pv. Flaccumfaciens).

As shown in the mean test Dunnet ( $p>0.05$ ) (Table 2), mean cooking time (30.9 min) and bean protein content (20\%) of the cultivar IAC 1850 were similar to those of the controls. These results qualify the cultivar to be able to be well received by the consumer market.

\section{TECHNICAL RECOMMENDATIONS AND SEED PRODUCTION}

The cultivar IAC 1850 is recommended for cultivation in the rainy, dry, and winter crop seasons in the states of São Paulo e Goiás and in the rainy and dry seasons in the states of Paraná, Santa Catarina, Rio Grande do Sul, and Mato Grosso do Sul. A between-row spacing of $50 \mathrm{~cm}$ and 10 plants per linear meter, resulting in 200,000 plants per hectare.

IAC 1850 was registered in 2018 in the MAPA/RNC under number 38613 and has seed production available in the Núcleo de Produção de Sementes do Instituto Agronômico - IAC.

\section{REFERENCES}

Carbonell SAM, Chiorato AF, Gonçalves JGR, Perina EF and Carvalho CRL (2010) Tamanho de grão comercial em cultivares de feijoeiro. Ciência Rural 40: 2067-2073.

CIAT - International Center for Tropical Agriculture (2016) Beans. Available at: <https://ciat.cgiar.org/what-we-do/breeding-better-crops/ beans/>. Accessed on May 27, 2019.

CONAB-Companhia Nacional de Abastecimento (2018) Acompanhamento da safra brasileira de grãos Safra 2017/18. Available at: < https:// www.conab.gov.br/ >. Accessed on Dec 10, 2018.

Fageria N, Stone L, Santos AD and Carvalho M (2015) Nutrição mineral do feijoeiro. Embrapa, Brasília, 394p.
Li H, Li J, Shen Y, Wang J and Zhou D (2017) Legume consumption and all-cause and cardiovascular disease mortality. Biomed Research Internacional 2017: 6.

Silva OF and Wander AE (2016) O feijão-comum no Brasil passado, presente e futuro. Embrapa Arroz e Feijão, Santo Antônio de Goiás, $63 p$ (Documento 287).

Singh SP (1992) Common bean improvement in the tropics. Plant Breeding Reviews 10: 391.

Wutke EB, Carbonell SAM, Chiorato AF, Esteves JAF, Ito MF, Stein CP, Brunini $O$ and Gallo PB (2014) Feijão (Phaseolus vulgaris L.). In Aguiar ATE, Gonçalves C, Paterniani MEAGZ, Tucci MLS and Castro CEF (eds) CEF Boletim 200: Instruções agrícolas para as principais culturas econômicas. Instituto Agronômico, Campinas, 460p. 